by Enerst Tata ${ }^{1 *}$, Cheo Emmanuel Suh ${ }^{2,3}$, Akumbom Vishiti ${ }^{4}$, Elisha Mutum Shemang, and Kevin Ijunghi Ateh ${ }^{l}$

\title{
Emplacement timing, temperature, and redox conditions of the Kambélé auriferous pluton, Batouri gold District, SE Cameroon
}

\author{
${ }^{1}$ Department of Mining and Mineral Engineering, National Higher Polytechnic Institute (NAHPI), The University of Bamenda, P.O. Box 39 \\ Bambili, North West Region, Cameroon; *Corresponding author, E-mail: etata75@gmail.com \\ ${ }^{2}$ Department of Geology, Mining and Environmental Science, The University of Bamenda, P.O. Box 39 Bambili, North West Region, Cameroon \\ ${ }^{3}$ Economic Geology Unit, Department of Geology, University of Buea, P.O. Box 63, Buea, South West Region, Cameroon \\ ${ }^{4}$ Department of Civil Engineering, The University Institute of Technology (IUT), University of Douala, P.O. Box 8698 Douala, Littoral \\ Region, Cameroon \\ ${ }^{5}$ Department of Earth and Environmental Sciences, Botswana International University of Science and Technology, Private Bag 16, Palapaye, \\ Botswana
}

(Received: July 23, 2020; Revised accepted: June 10, 2021)

https://doi.org/10.18814/epiiugs/2021/021013

The Kambéle auriferous pluton in south-eastern Cameroon is within the Central African Fold Belt (CAFB). New zircon LA-ICP-MS U-Pb ages, REEs patterns, zircon $\mathrm{Ce}^{4+}$ / $\mathrm{Ce}^{3+}$ ratios, and Ti-in-zircon thermometry, have been used to decipher the timing of mineralisation, redox conditions and emplacement temperature of the pluton. Cathodoluminescence images of 12 representative zircon grains from the Kambéle pluton reveal two types of zircon grains: type 1 grains are characterized by dark cores, serrated margins and poorly defined zonation; type 2 grains are euhedral to subhedral, elongated, with core to rim zonation and with darker rims indicative of a pristine magmatic source. The zircon grains are depleted in light rare earth elements. Chondrite-normalised REE patterns show undefined Ce anomalies and negative Eu anomalies indicating moderately oxidised to reduced conditions. Zircon $\mathrm{U}-\mathrm{Pb}$ age of the granitoid is constrained to Neoproterozoic with a mean age of $589 \pm 36$ Ma indicating gold mineralisation during the Pan African orogeny. Crystallization temperatures range from $525-1033^{\circ} \mathrm{C}$ with a mean temperature of $\sim 712^{\circ} \mathrm{C}$, concomitant with granitoid emplacement temperatures within the Adamawa Yadé Domain of the $C A F B$.

\section{Introduction}

The Kambélé I, II and III (hereafter referred to simply as Kambélé; Fig. 1) pluton lies within the Adamawa Yadé Domain (AYD) in the eastern region of Cameroon. It forms part of the Central African Fold Belt well known for its gold mineralization associated with felsic granitic plutons (Ateh et al., 2017; Tata et al., 2018; Ngatcha et al., 2019). Plutons within the Adamawa Yadé Domain have been charac- terized based on their petrochemistry, as well as their significance in the genesis of gold mineralization (Asaah et al., 2014; Tata et al., 2018, Ngatcha et al., 2019). Within this domain granitic plutons hosting mineralization reveal a mean age of $620 \pm 2 \mathrm{Ma}$ in the Batouri gold district (Asaah et al., 2014). This age is similar to ages reported by Ateh et al. (2017) in the Bétaré Oya gold district that lies north of the Batouri district. Although the age of plutons within specific sites along the Central African Fold Belt has been constrained, it is important that new LA-ICP-MS U-Pb ages of plutons further south be determined to refine the age bracket since it has a direct bearing on gold exploration ventures.

Zircon has ubiquitous occurrence within crustal rocks, mantle xenoliths, lunar rocks, meteorites and tektites (Speer, 1980). The exceptional robustness of zircon and its ability to structurally accommodate elements that are part of key isotopic studies is primordial in geothermometry (Ferry and Watson, 2007) and is also used as geochemical tracer in the study of ancient magmatic and hydrothermal events (Scherer et al., 2007). The chemical composition of zircon has been used to decipher the various magmatic processes such as fractional crystallization, interaction with hydrothermal fluids and/or magma mixing (Erdmann et al., 2013). Cathodoluminescence (CL) images of zircon grains reveal their chemical zonation and the internal growth structure which are essential in understanding the evolution of the magmatic system (Samperton et al., 2015). According to Gagnevin et al. (2010) zircon is a stable mineral that can crystallize over a wide range of magmatic temperatures especially depending on the bulk composition of the host magma. Such temperatures are estimated using the content of Ti in zircon (Gordon et al., 2009). So far, temperature estimates for the magmatic event responsible for Au mineralization within this auriferous belt are not available.

Magmatic-hydrothermal deposits have a persistent spatial association with oxidized calc-alkaline intrusions (Candela, 1992; Hedenquist and Lowenstern, 1994). The presence of Ce in the crystal lattice of zircon is also important in determining the oxidation state of magma at 


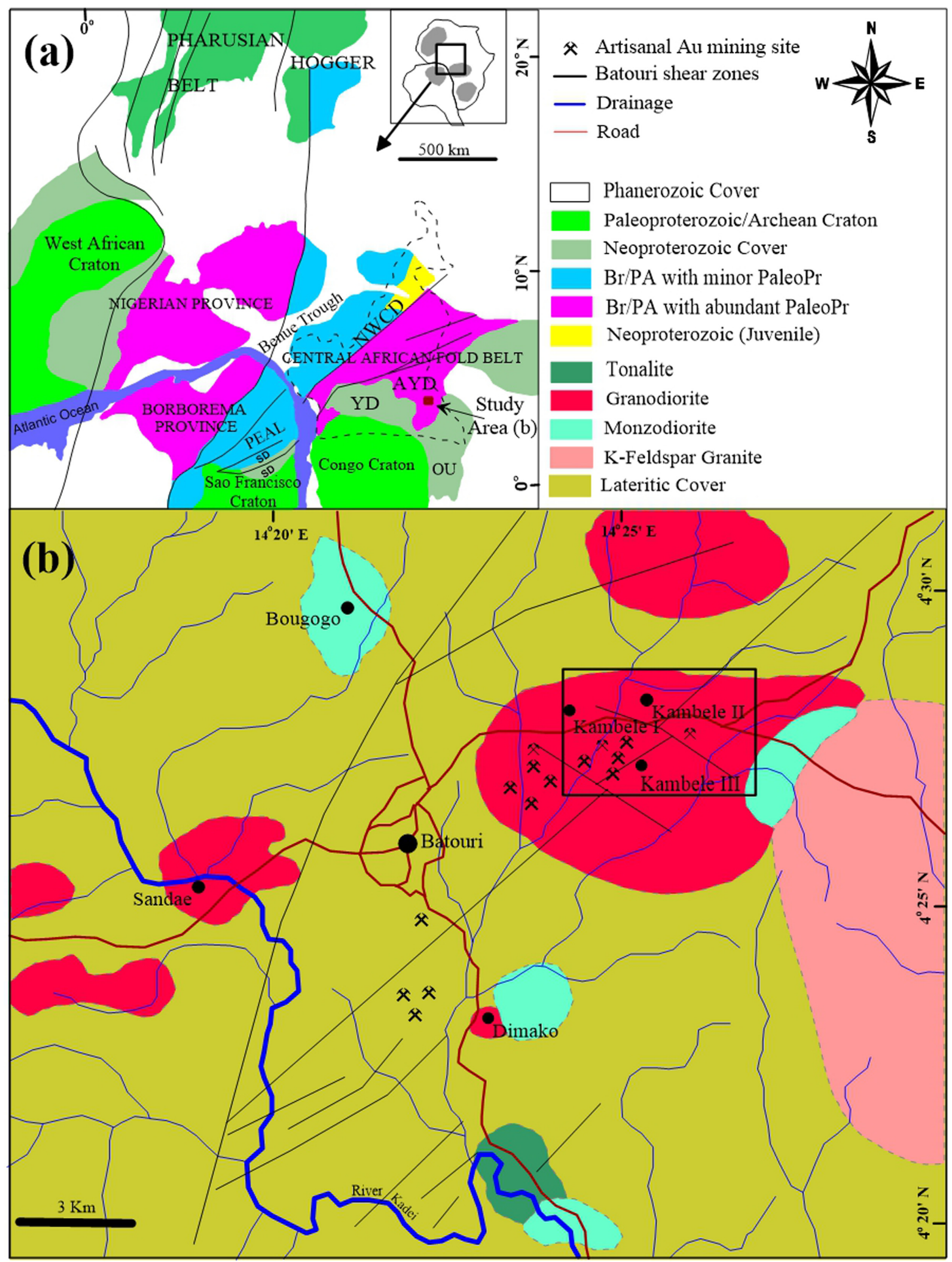

Figure 1. A section of West Gondwana about 500 Ma showing inferred geological provinces and potential correlations from Brazil to WestCentral Africa. Legend: Br/PA, Braziliano/Pan-African; PaleoPr, Palaeoproterozoic crust. OU, Oubanguide; PEAL, Pernambuco-Alagoas domain; SD, Sergipano domain; (Modified from Van Schmus et al., 2008).

the time of crystallization. The $\mathrm{Ce}^{4+} / \mathrm{Ce}^{3+}$ ratios in zircon grains provide a useful tool for evaluating the oxidation state of the intrusions and consequently their suitability for hydrothermal Au mineralization
(Ballard et al., 2002; Nardi et al., 2013). Although Asaah et al. (2014) inferred moderately oxidised conditions for some plutons in the Batouri gold district from the presence of magnetite-ilmenite series minerals 
the oxidation state of the Kambélé granitic intrusion remains unknown.

In this contribution, we present new zircon LA-ICP-MS U-Pb ages, oxidation state and the Ti-in-zircon temperatures of the Kambélé granitoid with a focus on determining the timing of granitoid emplacement, redox conditions and the emplacement temperature. This contribution explicates the characteristics of the gold-related Kambélé pluton and will help in expediting exploration efforts for intrusion-related gold deposits in the Neoproterozoic Central African Fold Belt in Cameroon and beyond.

\section{Location and Geologic Overview}

\section{Regional Geology}

The Batouri gold district of south eastern Cameroon constitutes part of the Adamawa Yadé lithostructural unit of the Central African Fold Belt (Toteu et al., 2004; Van Schmus et al., 2008; Asaah et al., 2014) north of the Congo Craton. This domain is the southernmost branch of the Pan-Africano-Braziliano mobile belt (Poidevin, 1983; Nzenti et al., 1988). According to Castaing et al. (1994) the evolution of the Central African Fold Belt can be attributed to the convergence and collision between the São Francisco-Congo Craton and the West African Craton (WAC) and a Pan African mobile belt. This belt underlies Cameroon, Chad and the Central African Republic, between the Congo Craton to the south and the Western Nigerian shield to the north (Toteu et al., 2004; Van Schmus et al., 2008). This mobile domain corresponds to the mobile belt of Central Africa consisting of an amalgamation of Precambrian terrains (Ferré et al., 2002; Tchameni et al., 2006, 2013) that show a long and complex crustal evolution with a strong overprint of Neoproterozoic events. Two phases of deformation have been defined in the AYD. The first is marked by a gently dipping foliation that is axial planar with small isoclinal folds, $\mathrm{N} 110^{\circ}-$ $\mathrm{N} 140^{\circ}$ mineral lineation, and asymmetrical garnet porphyroclasts defining a sinistral movement. The second deformation stage is characterized by the development of tight and upright folds with steeply dipping axial plane schistosity, plunging fold axes and stretching lineation that trend from NNE-SSW to NE-SW (Kankeu et al., 2012).

The AYD is dominated by a NE-SW regional-scale felsic calc-alkaline plutonic complex intruded into a Palaeoproterozoic basement (Tchameni et al., 2006). Lithologically, the AYD is underlain by a variety of granitic rocks including alkali-feldspar granite, quartz alkali granitoid, syeno-monzogranite, granodiorite, diorite, monzodiorite and tonalite (Asaah et al., 2014; Tata et al., 2018). These granitoids intrude high grade gneisses that represent a Palaeoproterozoic basement which was likely dismembered during the Pan African assembly of western Gondwanaland (Toteu et al., 2004; Van Schmus et al., 2008). Biotitegneiss xenoliths are ubiquitous in most granitoid rocks occurring in the area. These enclaves are believed to represent fragments of the underlying Palaeoproterozoic-Archaean basement rocks or Neoproterozoic high-grade metasedimentary rocks (e.g., Van Schmus et al., 2008; Asaah et al., 2014; Tata et al., 2018). Rocks of the AYD have been classified into three main groups, viz. (a) large supracrustal blocks of Palaeoproterozoic metasedimentary rocks and orthogneiss with assimilated Archaean crust similar to the Ntem Complex, (b) 612-600 Ma, low- to medium-grade metasedimentary and metavolcaniclastic rocks, and (c) 640-610 Ma syn- to late-tectonic granitoids of transitional composition and crustal origin (Toteu et al., 2004, 2006a; Van Schmus et al., 2008). Gold occurrences have been reported in the weathered over burden (Suh and Lehmann, 2003; Fon et al., 2012; Vishiti et al., 2015; Bissegue et al., 2019) and stream sediments (Omang et al., 2014) within the AYD.

\section{Batouri Gold Deposit Geology}

In the Batouri gold mining district, primary gold mineralization is related to hydrothermally altered Pan African granitoids (Asaah et al., 2014; Tata et al., 2018) cut across by small-scale high grade auriferous discordant quartz veins/veinlets in structurally favourable sites (Suh et al., 2006; Asaah et al., 2014; Vishiti et al., 2019). The veins are enclosed by hydrothermally altered zones traceable in the wallrock (Suh and Lehmann, 2003; Suh et al., 2006; Suh, 2008; Asaah et al., 2014) and the soils (Vishiti et al., 2015). According to Suh et al. (2006), the quartz veins are defined by NE-SW-trending shear zones which form part of the Central Cameroon Shear Zone system. The felsic plutons are sourced from a metaluminous, I-type parental magma of tonalitic affinity (Tata et al., 2018). Previous U-Pb dating of zircon from other gold-associated felsic plutons in the Batouri gold district yielded concordant ages of 619-624 $\pm 2 \mathrm{Ma}$ (Asaah et al., 2014), while Ar-Ar dating of the alkali feldspar granite yielded an age of 640-620 Ma (Toteu et al., 2004). According to Asaah et al. (2014), these ages indicate that the granitoids were emplaced during the collision of the West African Craton and the Congo Craton.

The granitoids reveal gold contents as high as $103.7 \mathrm{~g} / \mathrm{t}$ in areas which are well-defined by silicification and sulphidation/ferruginization alterations (Tata et al., 2018). The mineralized quartz veins show a characteristic stockwork texture with gold contents that vary from 0.04-53.5 g/t (Suh et al., 2006; Asaah, 2010; Vishiti et al., 2019; Tchouankam et al., 2020). The wallrock Au contents reach a high of $2.6 \mathrm{~g} / \mathrm{t} \mathrm{Au}$ (Suh et al., 2006) and concentrations ranging from 0.048 to $0.191 \mathrm{~g} / \mathrm{t}$ are recorded in the soils (Vishiti et al., 2015). Mineralogically the veins are composed of quartz \pm gold \pm carbonates \pm haematite \pm sulphides \pm chlorite \pm albite \pm epidote and few selvages of wallrock bearing sericite (Vishiti et al., 2019). Thus the quartz veins are ferruginized and sulphidized. In the Batouri gold district gold is mined by artisanal and semi-mechanized methods from weathered primary pyrite-bearing quartz veins, alluvial and eluvial occurrences. Here artisanal gold mining dates as far back as 1930's (Gazel and Gérard, 1954). While alluvial gold exploitation strictly follows the river channels, eluvial exploitation focuses on the weathered granitic bedrock and primary pyrite-bearing quartz veins some of which are exposed in pits.

\section{Analytical Methods}

\section{Sampling and Zircon Separation}

A granitoid sample with visible gold grains was obtained from the Kambélé drill core. Zircon separation from this sample and preparation was carried out at the Department of Earth Science, University of California Santa Barbara (UCSB) by standard crushing, gravimetric 
and magnetic separation technics. The core sample was crushed using a Brico Braun jaw crusher prior to milling in a disc mill wilfley and 12 zircon grains separated using methylene iodide heavy-liquid separation finished by magnetic separation. The zircon grains were manually panned followed by hand-picking under a binocular microscope and thermally annealed at $850^{\circ} \mathrm{C}$ in quartz glass beakers for 60 hours followed by ultrasonic washing in $4 \mathrm{~N} \mathrm{HNO}_{3}$. They were rinsed in ultra-pure water, prior to further washing in warm $4 \mathrm{~N}$ $\mathrm{HNO}_{3}$. Possible surface $\mathrm{Pb}$ contamination was removed by further rinsing in ultra-pure water. The annealed and cleaned zircon fraction was then chemically ground in $200 \mu \mathrm{L} 29 \mathrm{~N} \mathrm{HF}$ and $20 \mu \mathrm{L} 8 \mathrm{~N}$ $\mathrm{HNO}_{3}$ at $180^{\circ} \mathrm{C}$ in modified $1.5 \mathrm{~mL}$ Teflon micro-centrifuge tubes in a Parr bomb for 12 hours. Post-annealing, grains were mounted in EpoFix Resin and Hardener and polished with a paste made up of 6 and $1 \mathrm{~mm}$ diamond halfway through to expose a cross-section through individual crystals.

\section{Zircon Imaging and U-Pb Measurement}

Cathodoluminescence (CL) images were obtained with a JEOL T300 scanning electron microscope (BSU) and FEI XL30 FEG-SEM (PU), both with a Gatan Mini CL. The selected zircon grains were analysed in situ by LA-ICP-MS at the Department of Earth Science, UCSB. The samples were mounted within a two-volume ablation cell (Laurin Technic, Australia) and ablated by a Resolution S-155 193 nm ArF Excimer (Resonetics) laser system connected to a ThermoScientific Element 2 sector field ICP-MS. Ablation occurred in a 0.60 $\mathrm{L} / \mathrm{min}$ He stream, which was mixed after ablation with $0.004 \mathrm{~L} / \mathrm{min}$ $\mathrm{N} 2$ and Ar as the sample carrier gas. The purity of the gas is reported with $99.999 \%$ accuracy. Laser spot sizes were $26 \mu \mathrm{m}$ for GJ-1 and Plešovice standard zircons and $50 \mu \mathrm{m}$ for the 91,500 reference zircon; a spot size of $26 \mu \mathrm{m}$ and a pulse rate of $5 \mathrm{~Hz}$ were used for unknowns. The samples were pre-ablated before the actual analysis started in order to prevent the measurement of impurities on the polished grain surfaces. The accuracy of the analyses was controlled through repeated measurements of the Plešovice reference zircon (concordia age $=$ $338.7 \pm 2.1 \mathrm{Ma}$, MSWD of concordance $=1.04$, probability of concordance $=0.31, \mathrm{n}=6$ ) and the 91,500 reference zircon (concordia age $=$ $1061.7 \pm 5.6 \mathrm{Ma}$, MSWD of concordance $=0.054$, probability of concordance $=0.82, \mathrm{n}=8$ ). Results are in good agreement with the published values of $337.13 \pm 0.37 \mathrm{Ma}$ for the Plešovice reference zircon (Sláma et al., 2008) and 1065 \pm 0.3 Ma for the 91,500 reference zircon (Wiedenbeck et al., 1995).

\section{Zircon REEs Concentration}

The zircon grains were subjected to in situ analyses for trace elements using a Laser Ablation-Inductively Coupled Plasma Mass Spectrometer (LA-ICP-MS). The laser-ablation system is a Continuum Surelite I-20 Q-switched Nd: YAG laser with a fundamental infrared (IR) wavelength at $1.064 \mathrm{~nm}$ and a pulse width of 5-7 ns. Two frequency doubling crystals provide second and fourth harmonics in the visible (VIS, $532 \mathrm{~nm}$ ) and ultraviolet (UV, $266 \mathrm{~nm}$ ), respectively. The UV beam was used for the trace element analyses reported in this paper. The analyses have been done with a pulse rate of $4 \mathrm{~Hz}$ (pulses per second) and beam energy of $1 \mathrm{~mJ}$ per pulse, producing a spatial resolution of
$30-50 \mu \mathrm{m}$. Small grains (less than $100 \mu \mathrm{m}$ across) were analyzed using a pulse rate of $2 \mathrm{~Hz}$ and beam energy of about $0.5 \mathrm{~mJ}$ per pulse, achieving spatial resolution of about $30 \mu \mathrm{m}$. The NIST 610 standard glass was used as the external calibration standard. Quantitative results for 20 trace elements (Ti, Y, La, Ce, Pr, Nd, Sm, Eu, Gd, Tb, Dy, Ho, Er, Tm, $\mathrm{Yb}, \mathrm{Lu}, \mathrm{Hf}, \mathrm{Pb}, \mathrm{U}$, and $\mathrm{Th}$ ) in ppm were obtained through calibration of relative element sensitivities using the NIST-610 standard glass, and normalization of each analysis to the electron-probe data for $\mathrm{Hf}$ as an internal standard. The reference data for the NIST 610 calibration standard glass are given in Norman et al. (1998). The NIST 610 standard glass was analyzed as an unknown once during the analyses for data quality assessment. The precision and accuracy of these NIST 610 analyses are $2-5 \%$ for $\mathrm{REE}, \mathrm{Pb}, \mathrm{Th}$, and $\mathrm{U}$ at the ppm concentration level.

\section{Zircon Saturation Temperatures}

The Ti measurement was done using instrumental conditions for spot analysis similar to those reported in Harrison and Schmitt (2007). Temperatures were calculated from the Ti concentration measurements based on the calibration presented in Ferry and Watson (2007), $\log (\mathrm{ppm} \mathrm{Ti})=5.711-4800 / \mathrm{T}(\mathrm{K})+\log \left(a \mathrm{TiO}_{2}\right)$. The activities of $\mathrm{SiO}_{2}$ and $\mathrm{TiO}_{2}$ were set at unity in the calculations on the basis that the samples contained quartz and rutile. Uncertainties of $\pm 25^{\circ} \mathrm{C}$ were assigned for the calculated temperatures. This is because most granites lack rutile at crystallization onset implying that $a \mathrm{TiO}_{2}$ must have been below unity when the zircon formed. Although granites are $\mathrm{SiO}_{2}$-rich, $a \mathrm{SiO}_{2}$ can be below unity during early zircon crystallization, because quartz is normally not present at near liquidus conditions. The possible systematic errors such as misestimating the $\mathrm{SiO}_{2}$ and $\mathrm{TiO}_{2}$ activity and the contribution of $\mathrm{Ti}$ from non-zircon sources has been deemed to likely outweigh the analytical errors.

\section{Results}

\section{Zircon Grains Morphology and Composition}

Cathodoluminescence images of the 12 zircon grains show variable morphologies (Fig. 2). Two subgroups of zircon grains were identified. The first set of zircon grains is prismatic (EL5b, E9a, E24L13a, E24L13b, E24L13c and ES6b), euhedral to subhedral (ES6b, EL9a, EL5b) with serrated (E20a and E20b) to sub rounded edges (E24L13a, EL5a, EL9c, EL9d). A second set of the zircon grains is characterised by well-developed oscillatory, concentric and sector growth zoning patterns (EL5b, EL9a, EL9c, ES6b, and E24L13d) while in others the cores are brighter (EL9a, EL5b, and E24L13a) than the rims. Fractured zircon grains reveal cores that are darker than the rims (EL5a, EL9b, and E24L13b). In other cases the zircon grains have thin darker rims (E2a; EL5a, EL5b, E24L13b) compared to the brighter poorly developed zonation to well-developed oscillatory zoned cores.

The REEs concentration alongside $\mathrm{Ti}, \mathrm{Y}, \mathrm{Pb}, \mathrm{Hf}, \mathrm{U}$, and Th data of the 12 zircon grains are presented in Table 1 . In this contribution, the Ti concentration in the zircon grains varies from as low as below detection limit ( $\sim 0.01 \mathrm{ppm}$; ET4) up to $35.9 \mathrm{ppm}$ in zircon grain ET6, meanwhile these same grains have $Y$ ranging from 48.7 to $2930 \mathrm{ppm}$. Radiogenic $\mathrm{Pb}$ varies from 0.357 to $49.30 \mathrm{ppm}$. Hf has a concentra- 


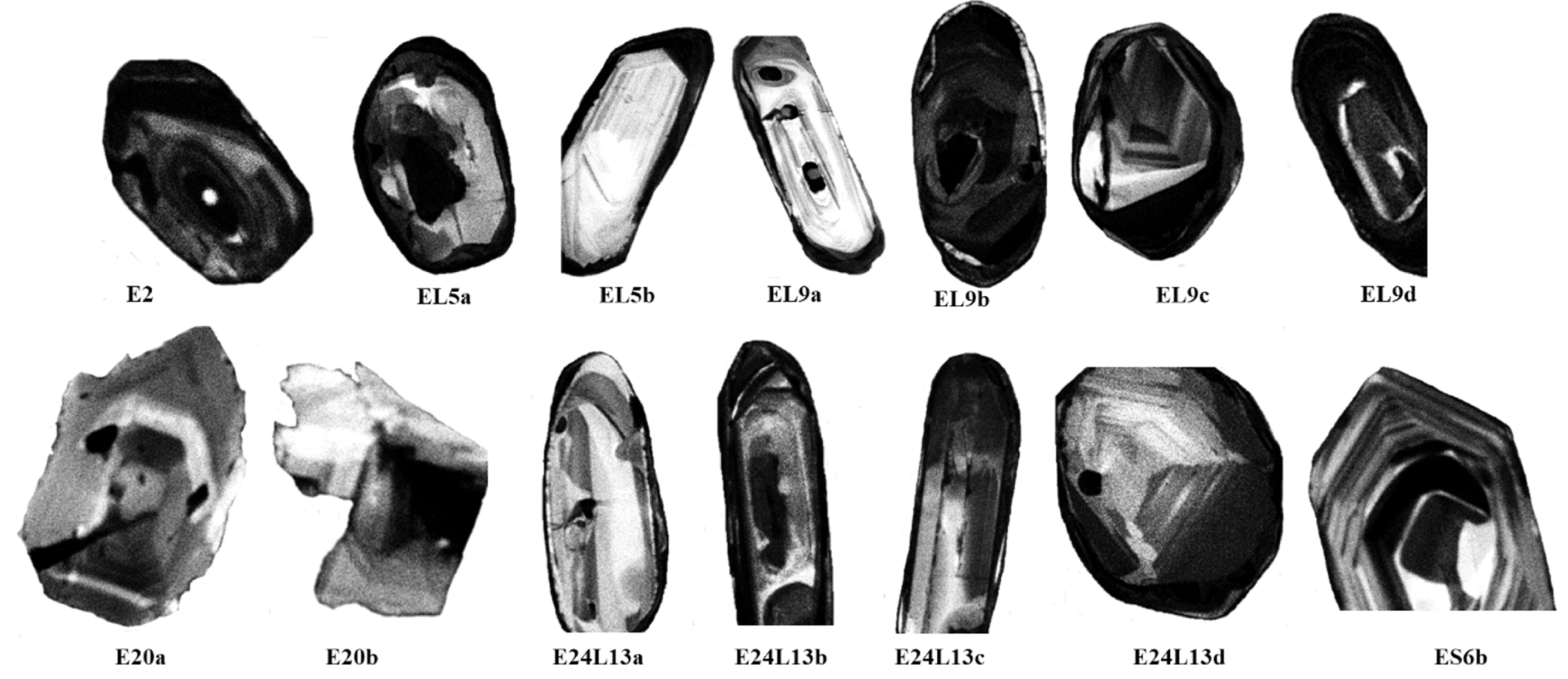

Figure 2. Representative Cathodoluminescence (CL) images of zircon grains from the Kambélé pluton.

tion that varies from 6560 to $12970 \mathrm{ppm}$. U and Th also vary in the analysed zircon grains from 63.3 and $1.99 \mathrm{ppm}$ to as high as 1495 and $265 \mathrm{ppm}$, respectively. This gives a $\mathrm{Th} / \mathrm{U}$ ratio that varies from 0.01 to 2.20. The total REEs abundance ( $\Sigma R E E$ ) ranges from 75.08 to 2441.6 . HREEs show high concentrations (Lu varying, from 192 (ET8) to 9.2 ppm (ET2) with an average of $50.33 \mathrm{ppm}$ ) in the studied zircon grains, whereas the LREEs show lower concentrations, with La being below instrumental detection limit. The Ce concentration varies enormously but generally remains low (from below detection limit for ET4 to $139 \mathrm{ppm}$ for ET8). The concentration values for Ce are generally higher than for neighbouring $\operatorname{Pr}$ (up to $14.9 \mathrm{ppm}$ though for zircon grains ET2, ET4 and ET9 it is below detection limit). The low con-

Table 1. Microchemical data for the zircon grains used in this study

\begin{tabular}{|c|c|c|c|c|c|c|c|c|c|c|c|c|}
\hline Zircon Grain & ET1 & ET2 & ET3 & ET4 & ET5 & ET6 & ET7 & ET8 & ET9 & ET10 & ET11 & ET12 \\
\hline $\mathrm{La}(\mathrm{ppm})$ & bdl & bdl & bdl & bdl & bdl & bdl & bdl & bdl & bdl & bdl & bdl & bdl \\
\hline $\mathrm{Ce}$ & 8.9 & 0.11 & 21.5 & bdl & 47 & 20.7 & 68.8 & 139 & 15.6 & 13.3 & 8.3 & 33.1 \\
\hline $\operatorname{Pr}$ & 1.53 & bdl & 7.7 & bdl & 12.3 & 2.24 & 14.9 & 33.6 & bdl & 3.2 & 1.76 & 10.3 \\
\hline $\mathrm{Nd}$ & 7.6 & bdl & 27.2 & bdl & 49 & 17.1 & 53.1 & 80 & 0.58 & 11 & 7.4 & 40.7 \\
\hline $\mathrm{Sm}$ & 3.48 & 0.16 & 20.3 & 0.11 & 26.2 & 19 & 45.3 & 39 & 1.43 & 8.2 & 10.9 & 30 \\
\hline $\mathrm{Eu}$ & 1.46 & bdl & 7.7 & bdl & 24 & 3.78 & 2.69 & 2.16 & 1.02 & 2.05 & 1.07 & 5.4 \\
\hline Gd & 5.9 & 1.33 & 45.4 & 0.35 & 29.3 & 60 & 83 & 74 & 5.9 & 21.8 & 27.7 & 36.5 \\
\hline $\mathrm{Tb}$ & 1.9 & 1.23 & 11.34 & 0.1 & 6.11 & 14.9 & 18.5 & 26.2 & 1.73 & 8.5 & 8.5 & 10.2 \\
\hline Dy & 16.7 & 23.3 & 93 & 2.31 & 68 & 125 & 155 & 275 & 18.8 & 105 & 91 & 102 \\
\hline Ho & 5.92 & 9.2 & 26.3 & 1.34 & 21.6 & 34.3 & 45.3 & 93.4 & 6.54 & 39.7 & 32.5 & 31.2 \\
\hline Er & 29.5 & 39.9 & 101 & 10.3 & 89 & 127 & 160 & 418 & 29.2 & 177 & 140 & 131 \\
\hline $\mathrm{Tm}$ & 7.54 & 7.1 & 22.5 & 3.57 & 22.4 & 24.4 & 28.8 & 98.7 & 5.6 & 42 & 33.2 & 33.8 \\
\hline $\mathrm{Yb}$ & 95.7 & 61.8 & 220 & 44.5 & 250 & 212 & 257 & 970 & 66.4 & 445 & 318 & 306 \\
\hline $\mathrm{Lu}$ & 25.6 & 9.2 & 55.8 & 12.5 & 34.5 & 35.5 & 41.1 & 192 & 12.4 & 75.1 & 57.7 & 52.5 \\
\hline$\Sigma \mathrm{REE}$ & 211.73 & 153.33 & 659.74 & 75.08 & 679.41 & 695.92 & 973.49 & 2441.06 & 165.2 & 951.85 & 738.03 & 822.7 \\
\hline $\mathrm{Ti}$ & 1 & 2 & 109 & bdl & 14.3 & 35.9 & 20.2 & 4.3 & 3.9 & 5.5 & 2 & 8.4 \\
\hline $\mathrm{Y}$ & 197 & 284 & 842 & 48.7 & 730 & 1071 & 1166 & 2930 & 244 & 1236 & 950 & 1077 \\
\hline $\mathrm{Pb}$ & 10.76 & 0.59 & 10.59 & 0.36 & 49 & 40.61 & 78.5 & 579 & 2.348 & 40.7 & 49.06 & 49.3 \\
\hline $\mathrm{U}$ & 205.6 & 223.2 & 390.2 & 125.8 & 634 & 63.3 & 155.3 & 1450 & 242.4 & 1332 & 1495 & 1366 \\
\hline Th & 19.1 & 1.99 & 25.6 & 1.27 & 7.61 & 139.8 & 265.5 & 500 & 9.63 & 128 & 149 & 149 \\
\hline $\mathrm{Th} / \mathrm{U}$ & 0.09 & 0.02 & 0.05 & 0.04 & 0.01 & 2.20 & 1.71 & 0.34 & 0.04 & 0.09 & 0.10 & 0.11 \\
\hline $\mathrm{Yb} / \mathrm{Sm}$ & 27.5 & 386.25 & 10.837 & 404.5 & 9.542 & 11.158 & 5.6733 & 24.8718 & 46.434 & 54.268 & 29.174 & 10.2 \\
\hline
\end{tabular}

$\mathrm{Bdl}=$ below detection limit 


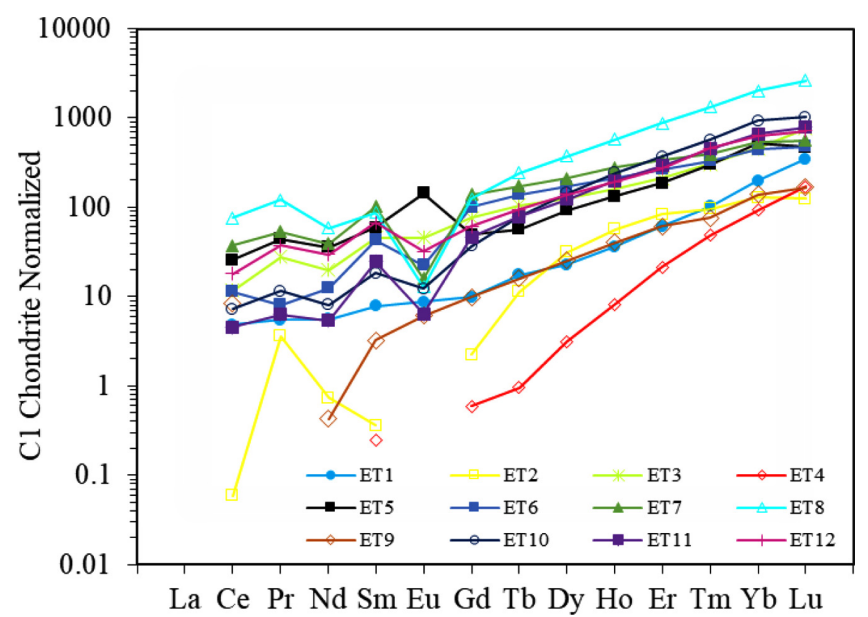

Figure 3. C1 chondrite normalised REE patterns for the Kambélé zircon grains. Sample numbers are same as for the geochemical data (Chondrite values of McDonough and Sun, 1995).

centration of Ce together with the below detection limits for $\mathrm{La}$ causes the zircon grains to lack a visible cerium anomaly. The grains show a variation in Eu concentration ranging from below detection limit to a maximum of $24 \mathrm{ppm}$. These zircon grains show a negative Eu anomaly but for grain ET5 where it is positive. Generally, there is an increase in concentration from the LREEs to the HREEs (Table 1, Fig. 3).

\section{Zircon U-Pb LA-ICP-MS Isotope Data}

The geochronological data for the 12 zircon grains are shown in Table 2. The analyses yielded Pan-African Neoproterozoic ages ranging from 551.1 to $648.5 \mathrm{Ma}$. These data on concordia plots indicate intercepts at $589 \pm 36 \mathrm{Ma}$ and $3850 \pm 1000 \mathrm{Ma}$ with a mean square weighted deviation (MSWD) of 306 (Table 2, Fig. 4). ${ }^{176} \mathrm{Hf} /{ }^{177} \mathrm{Hf}$ ratios are 0.28 for the zircon grains analysed while $\mathrm{EHf}_{\mathrm{t}}$ values range from -10.75 to -44.14 and the ${ }^{176} \mathrm{Lu} /{ }^{177} \mathrm{Hf}$ ratios are extremely low ranging from 0.00 to 0.012 .

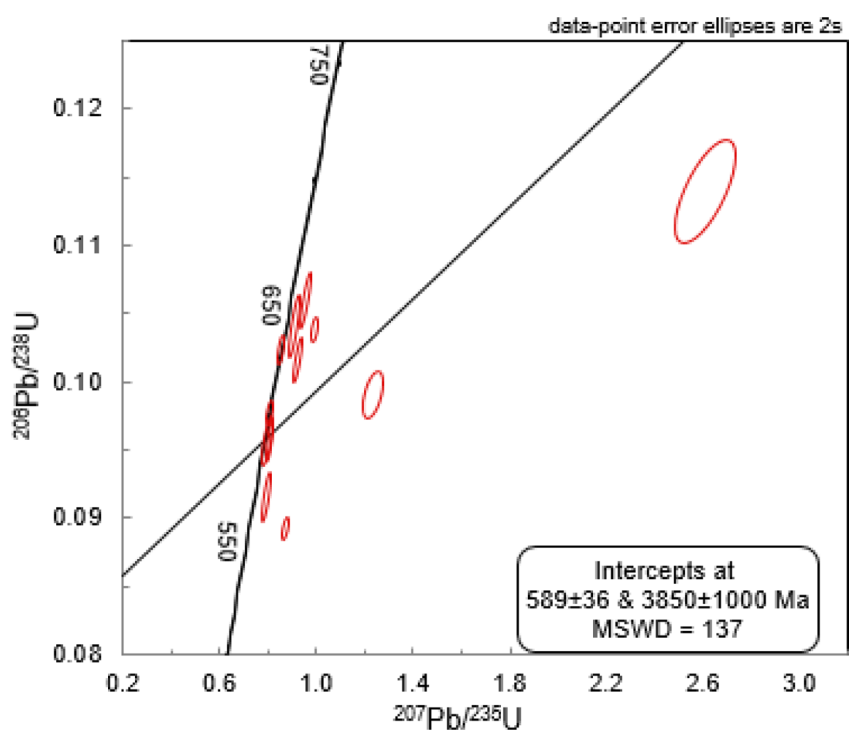

Figure 4. Concordia diagram of the zircon grains studied indicating Neoproterozoic Pan-African age for the Kambélé pluton.

\section{Ti-in-Zircon Temperatures}

Data obtained from the Ti-in-zircon thermometry are plotted in Fig. 5. The temperatures for the various zircon grains varied from $525-1034^{\circ} \mathrm{C}$. An average crystallisation temperature of $712^{\circ} \mathrm{C}$ for the granitoids within this gold district was obtained using the Ferry and Watson (2007) formula.

\section{Discussion}

\section{Characterisation of the Kambélé Granitoid Zircon Pop- ulation}

The zircon grains of the Kambélé pluton though partitioned into two broad groups have characteristics of magmatic zircon such as their elongated crystal morphology and concentric growth zoning

Table 2. U-Pb and age data for zircon grains from the Kambélé pluton

\begin{tabular}{|c|c|c|c|c|c|c|c|c|c|c|c|c|c|c|c|c|}
\hline $\begin{array}{l}\text { Zircon } \\
\text { Grains }\end{array}$ & $\begin{array}{l}\text { Final } \\
{ }^{207} \mathrm{~Pb} / \\
{ }^{206} \mathrm{~Pb}\end{array}$ & $\begin{array}{l}\text { Final } \\
{ }^{207} \mathrm{~Pb} / \\
{ }^{235} \mathrm{U}\end{array}$ & $\begin{array}{l}\text { Final } \\
{ }^{206} \mathrm{~Pb} / \\
{ }^{238} \mathrm{U}\end{array}$ & Rho & $\begin{array}{c}{ }^{207} \mathrm{~Pb} / \\
{ }^{206} \mathrm{~Pb} \mathrm{Age} \\
\text { (Ma) }\end{array}$ & $\begin{array}{l}{ }^{206} \mathrm{~Pb}{ }^{238} \mathrm{U} \\
\text { Age (Ma) }\end{array}$ & $\operatorname{Ref} a$ & $\begin{array}{l}{ }^{207} \mathrm{~Pb} \text { corr'd } \\
{ }^{206} \mathrm{~Pb} /{ }^{238} \mathrm{U} \\
\text { Age (Ma) }\end{array}$ & $\begin{array}{l}\text { Total } \\
\text { Hf (V) }\end{array}$ & $\beta \mathrm{Hf}$ & $3 \mathrm{Yb}$ & ${ }^{176} \mathrm{Hf} /$ & ${ }^{178} \mathrm{Hf} /$ & ${ }^{176} \mathrm{Lu} /$ & ${ }^{176} \mathrm{Yb} /$ & $\mathrm{EHf}_{\mathrm{t}}$ \\
\hline ET & 0.07 & 0.99 & 0.1 & & 910 & 636.9 & 636.9 & 630.51 & & 6 & -1.19 & 0.28 & 1.47 & 0 & 2 & -42.79 \\
\hline ET2 & 0.06 & 0.85 & 0.1 & 0.05 & 616 & 62 & 628.1 & 628.34 & & -1.36 & -1.21 & 0.28 & 1.47 & 0 & 0.04 & -39.54 \\
\hline ET3 & 0.07 & 0.87 & 0.09 & 0.63 & 949 & 551.1 & 551.1 & 543.09 & 9.61 & -1.36 & -1.2 & 0.28 & 1.47 & 0 & 0.02 & -40.81 \\
\hline ET4 & 0.06 & 0.8 & 0.1 & 0.6 & 596 & 601.4 & 601.4 & 601.54 & 9.68 & -1.34 & -1.11 & 0.28 & 1.47 & 0 & 0.01 & -44.13 \\
\hline ET5 & 0.09 & 1.23 & 0.1 & 0.52 & 1438 & 608 & 608.5 & 586.24 & & NA & NA & NA & NA & NA & NA & NA \\
\hline ET6 & 0.06 & 0.8 & 0.1 & 0.76 & 627 & 58 & 589.4 & 588.53 & 9. & -1.35 & -1.2 & 0.28 & 1.47 & 0 & 0.05 & -31.16 \\
\hline ET7 & 0.06 & 0.79 & 0.09 & 0.83 & 692 & 5 & 565.1 & 562.62 & 9.24 & -1.33 & -1.18 & 0.28 & 1.47 & 0 & 0.02 & -23.87 \\
\hline ET8 & 17 & 2.61 & 0.11 & 0.7 & 2504 & & 5 & 610.66 & & -1.37 & -1.16 & 0.28 & 147 & 0 & 11 & -14.92 \\
\hline ET9 & 0.06 & 0.8 & 0 . & 0.77 & 602 & 589.3 & 589.3 & 588.9 & 11.35 & -1.37 & 2 & 0.28 & 1.47 & 0 & 04 & -10.75 \\
\hline ET10 & 0.06 & 0.91 & 0 . & 0.86 & 07 & 638 & 050 & 636.28 & NA & NA & $1 \mathrm{~A}$ & 101 & NA & $1 \mathrm{~A}$ & A & NA \\
\hline ET11 & 0.06 & 0.95 & 0.11 & 0.89 & 768.8 & 648.5 & 648.5 & 646.15 & $\mathrm{~N}$ & NA & NA & NA & NA & NA & JA & NA \\
\hline ET12 & 0.07 & 0.92 & 0.1 & 0.84 & 781.5 & 623.9 & 623.9 & 620.32 & NA & NA & NA & NA & NA & NA & NA & NA \\
\hline
\end{tabular}




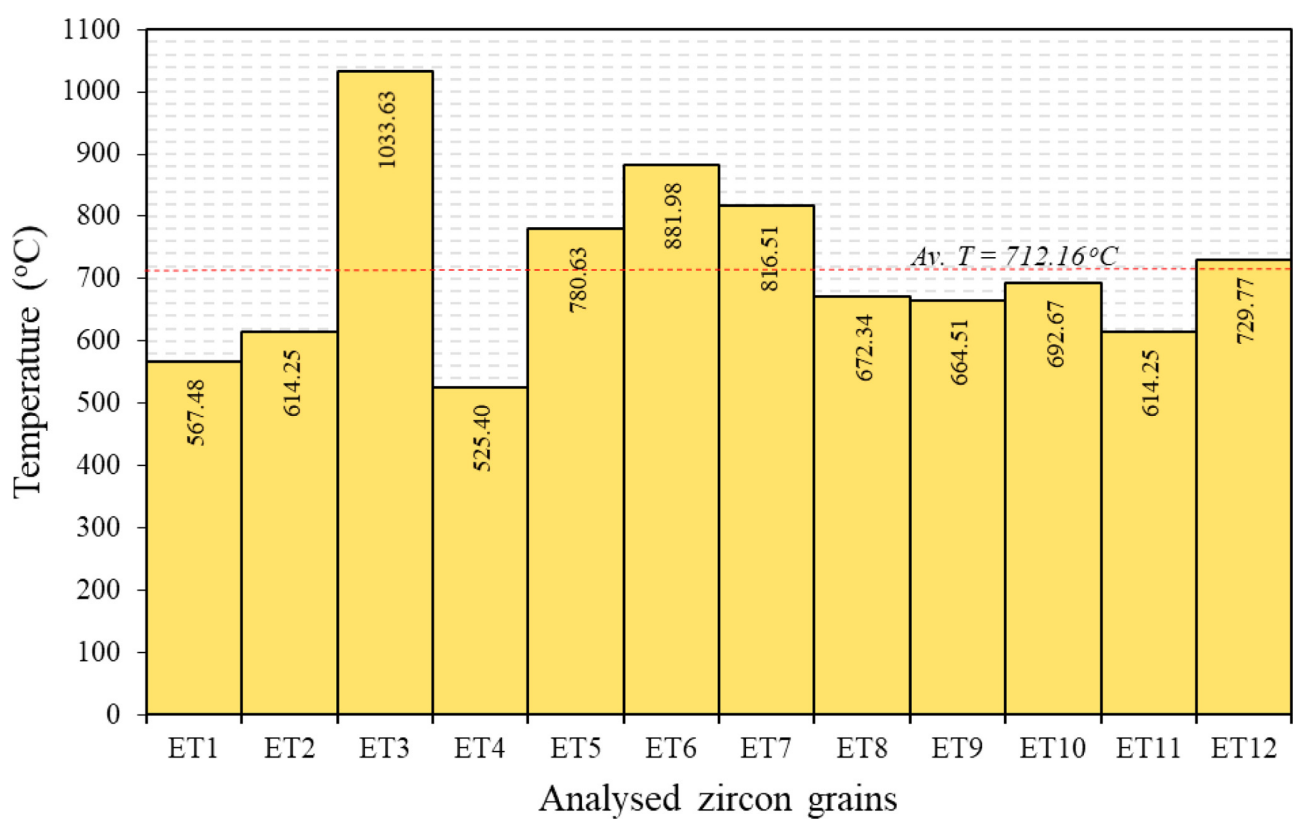

Figure 5. Granitoids crystallisation and mineralisation temperature of the Kambélé area.

(Fig. 2) which are analogous to the magmatic zircons described in Corfu et al. (2003). Some of the zircon grains also show slightly resorbed shapes with serrated margins (E20a and b), a characteristic that is common in both magmatic and metamorphic zircons (Corfu et al., 2003; Li et al., 2017). However, the influence of hydrothermal fluids in the metasomatic alteration process cannot be ruled out in the case of zircon grains having resorbed and serrated margins. The $\mathrm{Th} / \mathrm{U}$ ratios in the analysed zircon grains range between 0.01 and 2.1. Typical magmatic zircon has $\mathrm{Th} / \mathrm{U}$ ratio between 0.1 and 0.2 while highly metamorphic zircon grains have $\mathrm{Th} / \mathrm{U}$ ratios $<0.1$ (Belousova et al., 2002). As such the zircon grains from Kambélé are magmatic with mild hydrothermal overprints. This hydrothermal event could be the result of residual magmatic fluids co-genetic with the magma emplacement and the mobilisation of Au. The absence of inclusions such as garnet and kyanite which are indicative of metamorphic zircons also corroborate the fact that they have simply been affected by hydrothermal fluids without intense metasomatic alteration or growth from typical metamorphic processes. Moreover, other granitoids from other parts of the CAFB that have undergone similar tectonometamorphic and structural evolution have similar ages (e.g., Bouyo Houketchang et al., 2016; Ateh et al., 2017; Li et al., 2017; Embui et al., 2019; Bute et al., 2020). The discriminant diagrams: $U$ versus Th, $Y$ versus $U$ and $\mathrm{Yb}$ versus $\mathrm{Yb} / \mathrm{Sm}$ (Figs. 6a, b and c) show that the Kambélé pluton varies from granodiorite, granite, diorite to tonalite and are continentally sourced similar to other mineralised granitoids reported elsewhere within the CAFB (e.g., Kepnamou et al., 2017) and beyond (Sawaki et al., 2017; Bute et al., 2020).

Despite the fact that the REE abundances in the zircon grains vary, their patterns are usually similar in terrains within the CAFB. With the exception of $\mathrm{Ce}$, the concentrations of REEs in zircon grains from Kambélé increase from La to Lu which is concurrent with other plutons within the AYD (Mosoh Bambi et al., 2013; Ateh et al., 2017). Total REEs of the zircon grains that range from 75.1-679.4 ppm (average $355.9 \mathrm{ppm}$ ) is consistent with abundances for these same REEs measured in zircon grains from other mineral deposit-related granitoids within the CAFB in Cameroon (Mosoh Bambi et al., 2013; Ateh et al., 2017; Embui et al., 2019). These patterns derived from the normalised values which are consistent with zircon grains from other portions of the CAFB and most especially the AYD (Ateh et al., 2017) can therefore be used as a guide for further planning during mineral exploration ventures.

\section{Redox Conditions of the Kambélé Pluton}

In this study, we have demonstrated that the Ce concentration in the zircon grains of the Kambélé granitoid is generally high while the Eu anomaly is largely negative. According to Ballard et al. (2002) a positive $\mathrm{Ce}$ anomaly is interpreted as an abundance of $\mathrm{Ce}^{4+}$, or oxidising conditions, which allows $\mathrm{Ce}^{4+}$ to readily substitute for $\mathrm{Zr}^{4+}$ (Trail et al., 2011). A negative Eu anomaly is usually attributed to the presence of $\mathrm{Eu}^{2+}$ in the melt, or reducing conditions, since $\mathrm{Eu}^{2+}$ partitions less readily into zircon than $\mathrm{Eu}^{3+}$. However, many zircon grains may also exhibit both positive $\mathrm{Ce}$ and negative Eu anomalies, contradictorily indicating both oxidised and reduced conditions (Ballard et al., 2002). The presence of both cases in the Kambélé granitoids where some of the zircon grains display slight positive $\mathrm{Ce}$ anomaly and negative $\mathrm{Eu}$ anomaly points to the fact that the redox conditions during emplacement of the pluton were mildly oxidising to reducing (e.g., Hoskin and Schaltegger, 2003). Similar results were obtained by Asaah et al. (2010) for the Batouri granitoids using the magnetite-ilmenite series footprint.

\section{Kambélé Granitoid Age within the Context of Felsic Plu- tonism in Cameroon}

The geochronological data of the Kambélé pluton give a mean U$\mathrm{Pb}$ LA ICP-MS age of $589 \pm 36$ Ma (Fig. 4). This places the Kambélé granitoid within the Neoproterozoic. Similar data have been obtained for other granitoid occurrences within the Central Cameroon Shear zone and the Central African Fold Belt as a whole (Ateh et al., 2017; 

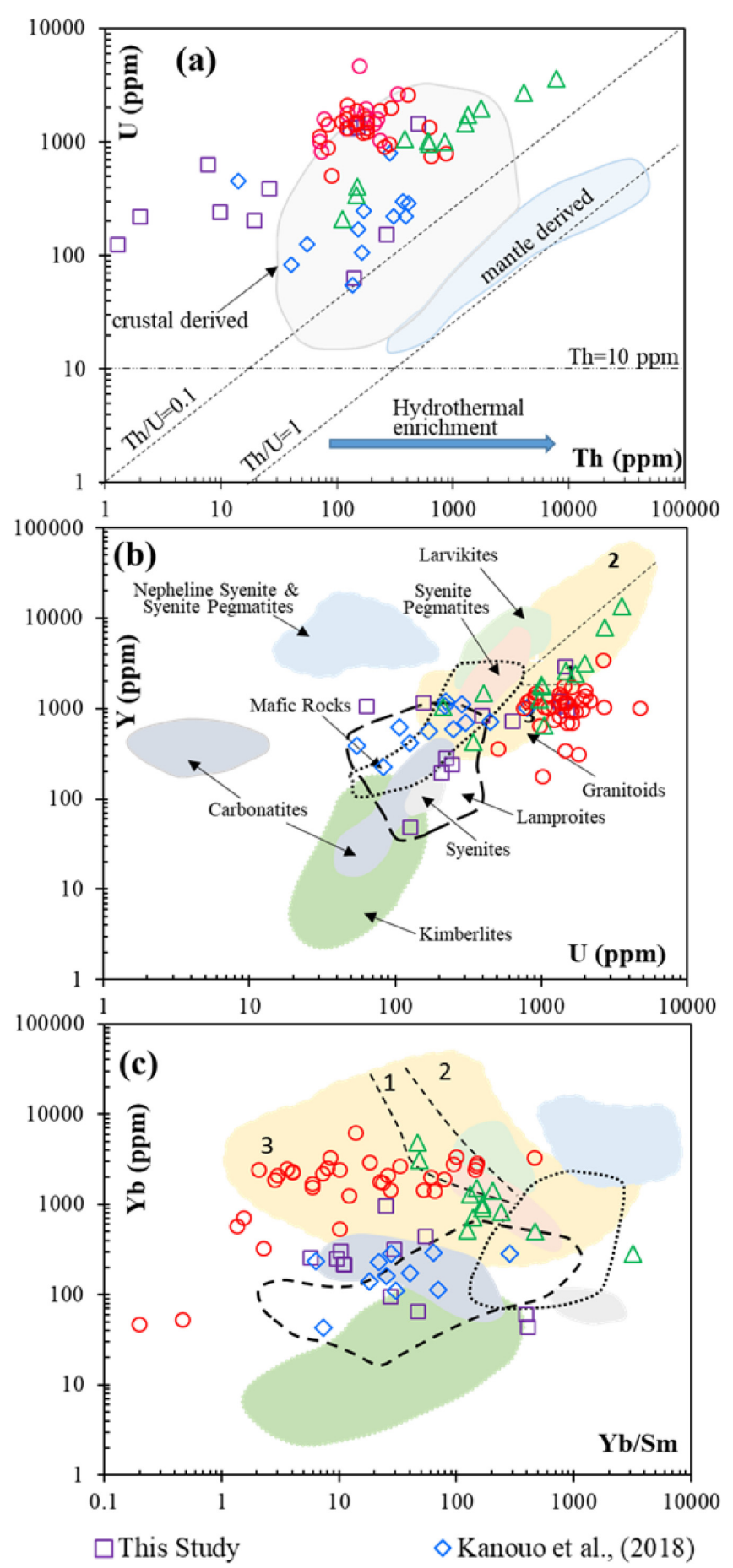

OAteh et al., (2017)

$\triangle$ Sawaki et al., (2017)

Figure 6. Geochemical characterization of the Kambélé zircon grains (a) $U$ versus Th, (b) $Y$ versus $U$, and (c) Yb versus $\mathrm{Yb} / \mathrm{Sm}$.

Embui et al., 2019; Bute et al., 2020). Thus, the $589 \pm 36$ Ma is interpreted as the age of emplacement of the Kambélé pluton. Geochronological data so far show that the late to post-collisional granitoids (ca 620-560 Ma) occur in many parts of the Central African Fold Belt (Toteu et al., 2004; Bouyo Houketchang et al., 2016). Similar occurrences have also been reported in the south-western Chad area of the CAFB and eastern Nigeria. The Kambélé granitoids were therefore emplaced towards the end of the Pan-African orogeny as older Neo- proterozoic ages between ca 740 and 630 Ma have been recorded for pre-collisional to syn-collisional granitoids at the northern margin of the CAFB in the Poli complex, Sinassi Batholitth, and Mayo Kebbi Batholith (Fig. 7). This occurrence suggests that the magmatism during the Pan-African orogeny started in the north and progressively extended to the south. Consequently, the concept of a regional scale batholith that covers the southern parts of Chad, western Central African Republic and Eastern Nigeria is ascertained. The magmatism forming the regional batholith resulted from melting of a primordial crust as a result of the collision of the West African Craton, the Congo Craton and the São Francisco Craton during the Pan-African-Braziliano orogeny. Some selected plutons with mineralisation potentials are shown in Fig. 7. Other Pan African granitoids dated with similar geochemical characteristics as the Kambélé granitoid include: the Poli complex granitoids made up of the Mayo Punko metadiorite, the Tchamba metadiorite, Gare metadiorite, and the Bakonwa foliated granite dated at 428-640 Ma using U-Pb on zircon grains. Within the North Western Cameroon Domain U-Pb age on zircon gives $621 \pm 3 \mathrm{Ma}$ for the Ekomedion Ngondo plutonic complex reported by Mosoh Bambi et al. (2013). In the AYD, Tchameni et al. (2006) using U-Pb obtained ages of $600 \mathrm{Ma}$ from zircon and 615-575 Ma from monazite for granitoids of the Ngaoundéré plutonic complex. The Ndokayo and Kadei plutons dated by Soba et al. (1991) using U-Pb on zircon grains gave 596.6 \pm 7.5 Ma. The Pala granitoids yielded 570 Ma using U-Pb on zircon grains (Penaye et al., 2006; Pouclet et al., 2006; Isseini et al., 2012) presenting ages slightly younger than the Kambélé granitoids but still within the Pan African.

\section{Neoproterozoic Granitoids and Gold Mineralisation: an African Perspective}

The late Neoproterozoic ( $\sim 600 \mathrm{Ma})$ has been linked with gold forming events in other parts of the world (e.g., Araújo et al., 2002) and could be extended to the Pan African-Braziliano Orogeny. This is the case with the $589 \pm 36$ Ma Kambélé granitoids. Shear zone emplaced granitoid-controlled lode gold mineralisation has been reported in several locations such as $580 \pm 30$ Ma NNE-trending shear zone hosted São Francisco gold deposits reported by Araújo et al. (2002). The northtrending D2 shear zone granitoids of the 545 Ma old Lega Dembi gold deposits of Ethiopia (Ghebread et al., 1992) and the North-trending Ouzzal shear zone hosted Amesmessa and Tirek gold deposits in Algeria (Aissa et al., 2014) which are $611 \mathrm{Ma}$ and $575 \mathrm{Ma}$, respectively also host gold mineralisation within the Pan African belt (Aissa and Marignac, 2017). The intrusion of gold-bearing quartz veins along the N- to NE-trending shear zone formed by the D2 deformation episodes at the end of the Pan African orogeny resulted in the formation of the Batouri gold district which centres on granitoid intrusions. Gold mineralisation in the Batouri gold district is therefore controlled by the major lithospheric mega shear zones and is confined to felsic plutons within the maximum extension zones developed during the extension phases of the deformation.

\section{Emplacement Temperature and Implication to Regional Gold Exploration}

We have shown that the crystallisation temperature of granitoids 


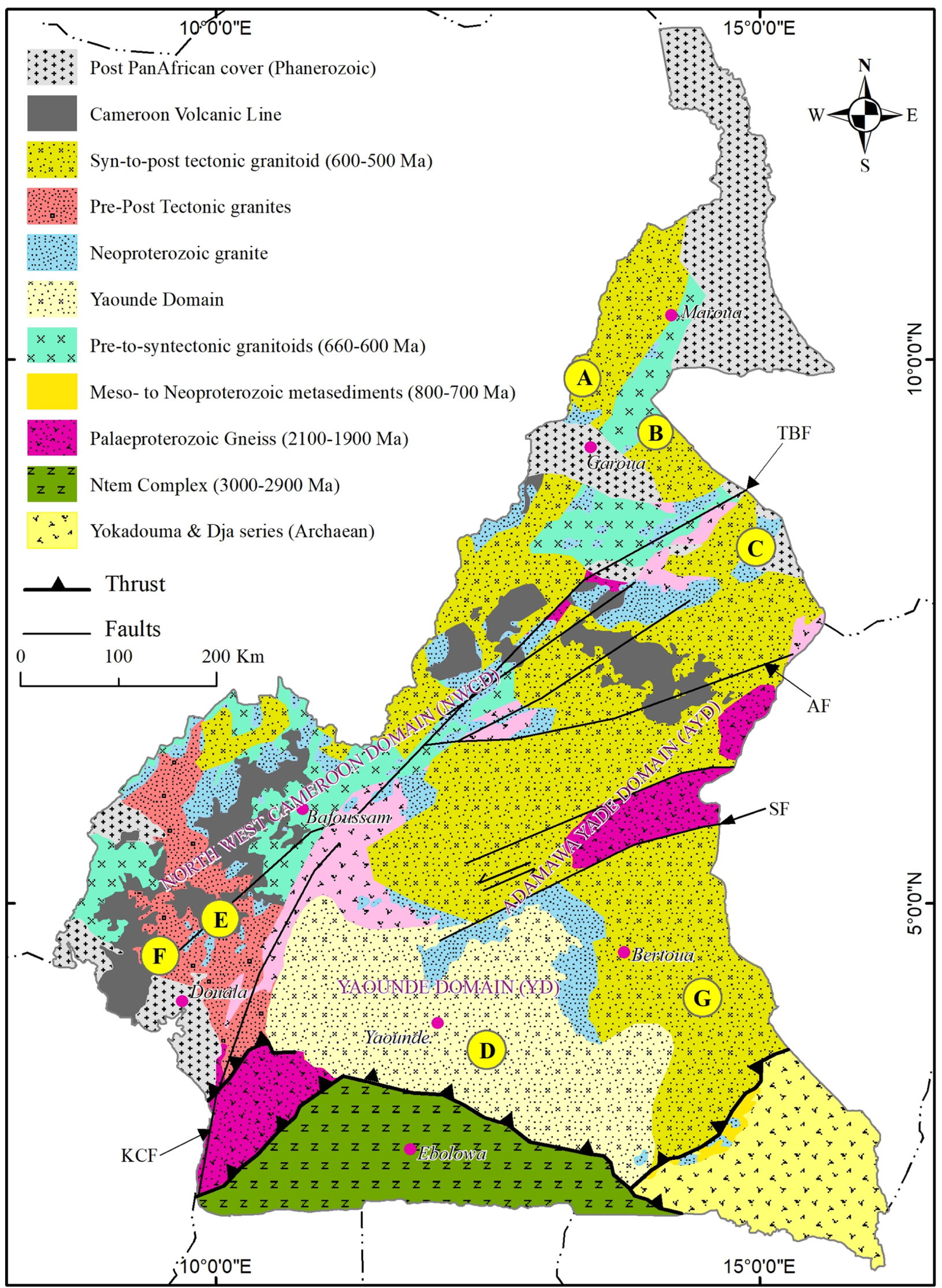

Figure 7. Comparative age range of some selected granitoids within the Central African Fold Belt (CAFB). (A) Mayo Oulo metagranodiorite (560-611 Ma); (B) Mayo Punko granodiorite (603-618 Ma); (C) Sinassi batholith (644-686 Ma); (D) Yaoundé leucosomes (626-654 Ma); (E) Ekomedion two mica granite (578 Ma); (F) Ngondo complex (602 Ma) and (G) Kambélé granitoid (589 $\pm 361 \mathrm{Ma})$. See text for references. SF, Sanaga fault; KCF, Kribi campo fault; AF, Adamawa fault. 
from the Kambélé area range from 525.40 to $1033.63^{\circ} \mathrm{C}$ obtained using Ti-in-zircon geothermometry. This gives an average temperature of $\sim 712^{\circ} \mathrm{C}$ which is unswerving granitoid emplacement temperature based on the classification of Chappell and White (1984). Similar temperatures have been reported in the northern parts of the CAFB by Bouyo Houketchang et al. (2016) for I-type granitoids using hornblende and plagioclase geothermometry. Temperature values of 698 to $720^{\circ} \mathrm{C}$ for the Djourde granitoids, 698 to $728^{\circ} \mathrm{C}$ for the Sinassi granitoids and 667 to $670^{\circ} \mathrm{C}$ for the orthogneiss (Bouyo Houketchang et al., 2016) are similar to that of the Kambélé pluton. Also, Ateh et al. (2017) reported temperature ranges from 625 to $775^{\circ} \mathrm{C}$ as the emplacement temperatures of the granitoids in the Bétaré-Oya gold district just north of the Kambélé pluton. Other Au mineralised granitoids such as those within the CAFB (Tchameni et al., 2006; Bouyo Houtketchang et al., 2016) also record the same temperature range for granitoids crystallisation in the northern portion of the AYD. This implies that the Kambélé pluton is coeval with a larger plutonic complex and has a high probability of hosting peripheral gold mineralization. This is significant in expanding the potential area for sustainable small scale gold mining operations in the area.

\section{Conclusion}

The zircon grains from the Kambélé pluton fall into two groups: magmatic zircons with oscillatory zones and magmatic metamict zircon grains which are characterized by corroded margins and dark cores with poorly defined internal zoning. The age of these zircon grains confine the emplacement of the pluton at $589 \pm 36 \mathrm{Ma}$ which is Neoproterozoic similar to other granitoid intrusions within the CAFB. This age bracket then provides constraints to the possible gold mineralisation periods within the Pan African in Cameroon and Africa at large.

Ti-in-zircon temperatures vary from $525.40-1033.63^{\circ} \mathrm{C}$ with an average temperature of $712.16^{\circ} \mathrm{C}$ obtained using the Ti-in-zircon thermometer and this temperature is similar to the temperatures of other plutons within the CAFB. Therefore, the temperature of crystallisation of the granitoids could play an important role in gold exploration ventures within the Central African Fold Belt in Cameroon.

The REE patterns indicate a depleted LREE concentration relative to the HREE. There is the absence of a defined $\mathrm{Ce}$ anomaly and the presence of negative Eu anomaly indicative of mild oxidising conditions. This indicates that there is a variation in the redox conditions of emplacement of the Kambélé granitoids compared to others within the Central African Fold Belt. Further research into constraining the redox conditions of these granitoids could better enhance exploration efforts.

\section{Acknowledgements}

This contribution is part of the study funded by the International Union of Geological Sciences (IUGS) under its "Resourcing Future Generations, RFG" programme coordinated at the University of Buea by Prof. CES. The Alexander von Humboldt Foundation (AvH Stiftung) through Prof. CES is also acknowledged for her support. Prof. John
Cottle of the Department of Earth Sciences and Earth Research Institute of UCSB is acknowledged for assisting with the LA-ICP-MS analyses. The authors acknowledge the editorial support of the editorin-chief, Prof. Jin-Yong Lee.

\section{References}

Aissa, D-E., and Marignac, C., 2017, Controls on gold deposits in Hoggar, Tuareg Shield (South Algeria). Journal of African Earth Sciences, v. 127, pp. 136-145.

Aissa, D.E., Bagui, M., Boutaleb, A., Boutrika, R., Cherbal, M., Kolli, O., Marignac, C.H., and Saad, W.1., 2014, Gold mineralisation at Hoggar Shield (South Algeria). $4^{\text {th }}$ Asia-Africa Mineral Resources Conference. 13 to 16 October 2014, Algiers-Algeria.

Araújo, M.N.C., Alves da Silva, F.C., Jardim de Sá, E.F., and Holcombe, R.J., 2002, Geometry and structural control of gold vein mineralisation in the Seridó Belt, north-eastern Brazil. Journal of South American Earth Sciences, v. 15 , pp. 337-348.

Asaah, A.V., 2010, Lode gold mineralisation in the Neoproterozoic granitoids of Batouri, South-eastern Cameroon. Ph.D. thesis, Clausthal University of Technology, $200 \mathrm{p}$.

Asaah, A.V., Zoheir, B., Lehmann, B., Frei, D., Burgess, R., and Suh, C.E., 2014 , Geochemistry and geochronology of the $\sim 620$ Ma gold associated Batouri granitoids, Cameroon. International Geology Reviews, v. 57, pp. $1485-1509$.

Ateh, K.I., Suh, C.E., Shemang, E.M., Vishiti, A., Tata, E., and Chombong, N.N., 2017, New LA-ICP-MS U-Pb ages, Lu-Hf systematics, and REE characterization of zircons from a granitic pluton in the Betaré-Oya Gold District, SE Cameroon. Journal of Geosciences and Geomatics, v. 5, pp. 267-283.

Ballard, J.R., Palin, J.M., and Campbell, I.H., 2002, Relative oxidation states of magmas inferred from Ce(IV)/Ce(III) in zircon: application to porphyry copper deposits of northern Chile. Contributions to Mineralogy and Petrology, v. 144, pp. 347-364.

Belousova, E.A., Griffin, W.L., O'reilly, S.Y., and Fisher, N.I., 2002, Igneous zircon: trace element composition as an indicator of source rock type. Contribution to Mineral Petrology, v. 143, pp. 602-622.

Bissegue, J-C., Tchameni, R., Etouna, J., Fosso, T.P., Tchuente, P., and Danra, M.G.G.B., 2019, Geological context mapping of Batouri Gold District (East Cameroon) from remote sensing imagery, GIS processing and field works. Journal of Geographic Information System, v. 11, pp. 766-783.

Blevin, P.L., and Chappell, B.W., 1992, The role of magma sources, oxidation states and fractionation in determining the granite metallogeny of eastern Australia. Transactions of the Royal Society of Edinburgh Earth Science, v. 83, pp. 305-316.

Bouyo Houketchang, H.M., Penaye, J., Njel, U.O., Moussango, A.P.I., Sep, J.P.N., Nyama, B.A., Wassouo, W.J.J., Abaté, M.E., Yaya, F., Mahamat, A., Hao, Y., and Fei, W., 2016, Geochronological, geochemical and mineralogical constraints of emplacement depth of TTG suite from the Sinassi Batholith in the Central African Fold Belt (CAFB) of northern Cameroon: Implications for tectonomagmatic evolution. Journal of African Earth Sciences, v. 116, pp. 9-41.

Bute, S.I., Yang, X., Suh, C.E., Girei, M.B., and Usman, M.B., 2020, Mineralogy, geochemistry and ore genesis of Kanawa uranium mineralization, Hawal Massif, eastern Nigeria terrane: Implications for uranium prospecting in Nigeria and Cameroon. Ore Geology Reviews, v. 120. doi:org/10.1016/j.oregeorev.2020.103381

Candela, P.A., 1992, Controls on ore metal ratios in granite-related ore systems: an experimental and computational approach. Transactions of the Royal Society of Edinburgh Earth Science, v. 83, pp. 317-326.

Castaing, C., Feybesse, J.L., Thieblemont, D., Triboulet, C., and Chevremont, P., 1994, Palaeogeographical reconstructions of the Pan-African/ 
Braziliano orogen: closure of an oceanic domain or intracontinental convergence between major blocks? Precambrian Research, v. 69, pp. 327-344.

Chappell, B.W., and White, A.J.R., 1984, Two contrasting granite types. Pacific Geology, v. 8, pp. 173-174.

Corfu, F., Hanchar, J.M., Hoskin, P.W.O., and Kinny, P., 2003, Atlas of zircon textures. In zircon, v. 53 (eds. J.M. Hancharand P.W.O. Hoskin). Mineralogical Society of America, Washington, DC, pp. 468-500.

Djouka-Fonkwe, M.L., Schulz, B., Tchouankoué, J.P., and Nzolang, C., 2008, Geochemistry of the Bafoussam Pan-African I- and S-type granitoids in Western Cameroon. Journal of African Earth Sciences, v. 50, pp. 148-167.

Embui, V.F., Suh, C.E., Cottle, J.M., Etame, J., Mendes, J., Agyingi, C.M., Vishiti, A., Shemang, E., and Lehmann, B., 2019, Zircon chemistry and new laser ablation $\mathrm{U}-\mathrm{Pb}$ ages for uraniferous granitoids in $\mathrm{SW}$ Cameroon. Acta Geochimica, v. 39, pp. 43-66.

Erdmann, S., Wodicka, N., Jackson, S.E., and Corrigan, D., 2013, Zircon textures and composition: refractory recorders of magmatic volatile evolution. Contributions to Mineralogy and Petrology, v. 165, pp. 45-71.

Ferré, E.C., Gleïzes, G., and Caby, R., 2002, Obliquely convergent tectonics and granite emplacement in the Trans-Saharan belt of Eastern Nigeria: a synthesis. Precambrian Research, v. 114, pp. 199-219.

Ferry, J.M., and Watson, E.B., 2007, New thermodynamic models and revised calibrations for the Ti-in-zircon and $\mathrm{Zr}$-in-rutile thermometers. Contributions to Mineralogy and Petrology, v. 154, pp. 429-437.

Fon, A.N., Che, V.B., and Suh, C.E., 2012, Application of electrical resistivity and chargeability data on a GIS platform in delineating auriferous structures in a deeply weathered lateritic terrain, Eastern Cameroon. International Journal of Geosciences, v. 3, pp. 960-971.

Fu, B., Zheng, Y-F., Wang, Z.R., Xiao, Y.L., Gong, B., and Li, S.G., 1999, Oxygen and hydrogen isotope geochemistry of gneisses associated with ultra-high pressure eclogites at Shuanghe in the Dabie mountains. Contributions to Mineralogy and Petrology, v. 134, pp. 52-66.

Gagnevin, D., Daly, J.S., and Kronz, A., 2010, Zircon texture and chemical composition as a guide to magmatic processes and mixing in a granitic environment and coeval volcanic system. Contribution to Mineralogy and Petrology, v. 159, pp. 579-596.

Gazel, J., and Gérard, G., 1954, Carte géologique de reconnaissance du Cameroun au 1/500 000, feuille Batouri-Est avec notice explicative, Memoir. Direction Mines Géologie, Yaoundé Cameroun.

Ghebreab, W., Yohannes, E., and Giorgis, L.W., 1992, The Lega Dembi gold mine: an example of shear zone-hosted mineralization in the Adola greenstone belt, Southern Ethiopia. Journal of African Earth Sciences and the Middle East, v. 15, pp. 489-500.

Gordon, S.M., Grove, M., Whitney, D.L., Schmitt, A.K., and Teyssier, C., 2009, Time-temperature-fluid evolution of migmatite dome crystallization: Coupled U-Pb age, Ti thermometry, and $\mathrm{O}$ isotopic ion microprobe depth profiling of zircon and monazite. Chemical Geology, v. 262, pp. 186-201.

Harrison, T.M., and Schmidt, A.K., 2007, High sensitivity mapping of Ti distributions in Hadean zircons. Earth and Planetary Science Letters, v. 261, pp. 9-18

Hedenquist, J.W., and Lowenstern, J.B., 1994, The role of magmas in the formation of hydrothermal ore deposits. Nature, v. 370, pp. 519-527.

Hoskin, P.W.O., Kinny, P.D., Wyborn, D., and Chappell, D.W., 2000, Identifying accessory mineral saturation during differentiation in granitoid magmas: An integrated approach. Journal of Petrology, v. 41, pp. 1365-1396.

Isseini, M., André-Mayer, A.S., Vanderhaeghe, O., Barbey, P., and Deloule, E., 2012, A-type granites from the Pan-African orogenic belt in southwestern Chad constrained using geochemistry, Sr-Nd isotopes and U$\mathrm{Pb}$ geochronology. Lithos, v. 153, pp. 39-52.

Kankeu, B., Greiling, R.O., Nzenti, J.P., Bassahak, J., and Hell, V.J., 2012, Strain partitioning along the Neoproterozoic Central Africa Shear Zone System: Structures and magnetic fabrics (AMS) from the Meiganga area, Cameroon. Neues Jahrbuch für Paläontologie Abhand-lungen, v. 265, pp. 27-47.

Kepnamou, A.D., Ganwa, A.A., Urs, K., Christoph, H.I.N., and Seguem, N., 2017, The Pan-African biotite-muscovite granite and amphibolebiotite granite of Doua (Central Cameroon): Zircon features, LA-MCICP-MS U-Pb dating and implication on their tectonic setting. Journal of Geosciences and Geomatics, v. 5, pp. 119-129.

Li, X-H., Chen, Y., Tchouankoue, J.P., Liu, C-Z., Li, J., Ling, X-X., and Tang, G-Q., 2017, Improving geochronological framework of the PanAfrican orogeny in Cameroon: New SIMS zircon and monazite U-Pb age constraints. Precambrian Research, v. 294, pp. 307-321.

Milési, J.P., Toteu, S.F., Deschamps, Y., Feybesse, J.L., Lerouge, C., Cocherie, A., Penaye, J., Tchameni, R., Moloto-A-Kenguemba, G., Kampunzu, H.A.B., Nicol, N., Duguey, E., Leistel, J.M., Saint-Martin, M., Ralay, F., Heinry, C., Bouchot, V., Doumnang Mbaigane, J.C., Kanda Kula, V., Chene, F., Monthel, J., Boutin, P., and Cailteux, J., 2006, An overview of the geology and major ore deposits of Central Africa: Explanatory note for the 1:4,000,000 map "Geology and major ore deposits of Central Africa". Journal of African Earth Sciences, v. 44, pp. 571-595.

Mosoh Bambi, C.K., Suh, C.E., Nzenti, J.P., and Frimmel, H.E., 2013, UMo mineralization potential in Pan-African granites, southwestern Cameroon: Economic geology of the Ekomédion prospect. Journal of African Earth Sciences, v. 65, pp. 25-45.

Nardi, L.V.S., Formoso, M.L.L., Müller, I.F., Fontana, E., Jarvis, K., and Lamarão, C., 2013, Zircon/rock partition coefficients of REEs, Y, Th, $\mathrm{U}, \mathrm{Nb}$, and $\mathrm{Ta}$ in granitic rocks: Uses for provenance and mineral exploration purposes. Chemical Geology, v. 335, pp. 1-7.

Ngatcha, R.B., Okunlol, O.A., Suh, C.E., Ateh, I.K., and Hofmann, A., 2019, Petrochemical characterization of Neoproterozoic Colomine granitoids, SE Cameroon: Implications for gold mineralization. Lithos, v. 34, pp. 175-192.

Ngatcha, R.B., Okunlola, O.A., Suh, C.E., Eben Mboe, E.R., and Fuanya, C., 2018, A review of granitoid-related gold mineralization styles and characteristics of the Neoproterozoic Eastern Gold Districts, Cameroon and the role of fluid inclusion studies in elucidating the genesis. Journal of Geosciences and Geomatics, v. 6, pp. 138-146.

Norman, M.D., Griffin, W.L., Pearson, N.J., Garcia, M.O., and O'Reilly, S.Y., 1998, Quantitative analysis of trace element abundances in glasses and minerals: A comparison of laser ablation inductively coupled plasma-mass spectrometry, solution inductively coupled plasmamass spectrometry, proton microprobe and electron microprobe data. Journal of Analytical Atomic Spectrometry, v. 13, pp. 477-482.

Nzenti, J.P., Barbey, P., Macaudiere, J., and Soba, D., 1988, Origin and the evolution of the late Precambrian high-grade Yaoundé gneisses (Cameroon). Precambrian Research, v. 38, pp. 91-109.

Omang, B.O., Bih, C.V., Fon, A.N., Embui, V., and Suh, C.E., 2014, Regional geochemical stream sediment survey for gold exploration in the Upper Lom Basin, Eastern Cameroon. International Journal of Geosciences, v. 5, pp. 1012-1026.

Pepogo, M.A.D., Ndougsa-Mbarga, T., Meying, A., Ngoh, J.D., MvondoOndoua, J., and Ngoumou, P.C., 2014, New geological and structural facts under the lateritic cover in Garga Saraki, Ndokayo (East Cameroon) area, from audiomagnetotellurics soundings. International Journal of Geophysics, v. 1, pp. 1-17.

Penaye, J., Kröner, A., Toteu, S.F., Van Schmus, W.R., and Doumnang, J.C., 2006, Evolution of the Mayo Kebbi region as revealed by zircon dating: An early (ca. $740 \mathrm{Ma}$ ) Pan-African magmatic arc in south-western Chad. Journal of African Earth Sciences, v. 44, pp. 530-542.

Poidevin, J.L., 1983, La tectonique Pan Africaine a la bordure nord du craton Congolais: L'orogenese des "oubanguides". In: $12^{\text {th }}$ Colloque on African Geology. Bruxelles, Abstract, 75.

Pouclet, A., Vidal, M., Doumnang, J.C., Vicat, J.P., and Tchameni, R., 2006, Neoproterozoic crustal evolution in southern Chad: Pan-African ocean basin closing, arc accretion, and late- to post-orogenic granitic 
intrusion. Journal of African Earth Science, v. 44, pp. 543-560.

Samperton, K.M., Schoene, B., Cottle, J.M., Brenhin, K.C., Crowley, J.L., and Schmitz, M.D., 2015, Magma emplacement, differentiation, and cooling in the middle crust: Integrated zircon geochronological-geochemical constraints from the Bergell Intrusion, Central Alps. Chemical Geology, v. 417, pp. 322-340.

Sawaki, Y., Suzuki, K., Asanuma, H., Okabayashi, S., Hattori, K., Saito, T., and Hirata, T., 2017, Geochemical characteristics of zircons in the Ashizuri A-type granitoids: An additional granite topology tool for detrital zircon studies. Island Arc, v. 26, pp. 1-19.

Scherer, E.E., Whitehouse M.J., and Munker, C., 2007, Zircon as a monitor of crustal growth. Elements, v. 3, pp. 19-24.

Sláma, J., Kosler, J., Condon, D.J., Crowley, J.L., Gerdes, A., Hanchar, J.M., Horstwood, M.S.A., Morris, G.A., Nasdala, L., Norberg, N., Schaltegger, U., Schoene, B., Tubrett, M.N., and Whitehouse, M.J., 2008, Plesovice zircon - A new natural reference material for $\mathrm{U}-\mathrm{Pb}$ and Hf isotopic microanalysis. Chemical Geology, v. 249, pp. 1-35.

Soba, D., Michard, A., Toteu, S.F., Norman, D.I., Penaye, J., Ngako, V., Nzenti, J.P., and Dautel, D., 1991, Données géochronologiques nouvelles (Rb-Sr, U-Pb, Sm-Nd) sur la zone mobile Pan Africaine de l'Est Cameroun: Age Protérozoïque Supérieur de la séries de Lom. Comptes Rendus de l'Académie des Sciences, v. 315, pp. 1453-1458.

Speer, J.A., 1980, Zircon. In: Ribbe PH (ed) Orthosilicates. Reviews in mineralogy, Mineralogical Society of America, Washington, DC, pp. 67-112.

Suh, C.E., 2008, Sulphide microchemistry and hydrothermal fluid evolution in quartz veins, Batouri Gold District (southeast Cameroon). Journal of the Cameroon Academy of Science, v. 8, pp. 19-30.

Suh, C.E., and Lehmann, B., 2003, Morphology and electron-probe microanalysis of residual gold grain at Dimako, south east Cameroon. Neues Jabrb. für Mineral. Monatsh, v. 6, pp. 225-275.

Suh, C.E., Lehmann, B., and Mafany, G.T., 2006, Geology and geochemical aspects of lode gold mineralization at Dimako-Mboscorro, SE Cameroon. Geochemistry: Exploration, Environment, Analysis, v. 6, pp. 295-309.

Tata, E., Suh, C.E., Vishiti, A., Shemang, E.M., Fon, A.N., Ateh, K.I., and Chombong, N.N., 2018, Wallrock alteration categories and their geochemical signatures in gold-bearing Neoproterozoic granitoids, Batouri Gold District, south-eastern Cameroon. Geochemistry: Exploration, Environment Analysis, v. 19, pp. 269-288.

Tchameni, R., Pouclet, A., Penaye, J., Ganwa, A.A., and Toteu, S.F., 2006, Petrography and geochemistry of the Ngaoundéré Pan-African granitoids in Central North Cameroon: Implications for their sources and geological setting. Journal of African Earth Sciences, v. 44, pp. 511-529.

Tchouankam, K.J., Mbog, M.B., Bayiga, E.C., Tassongwa, B., Ngon Ngon, G.F., Apouamoun, Y.R., Kenfact, J.V., and Etame, J., 2020, Economic potential of gold in Batouri (Eastern Cameroon). Earth Science Research, v. 9, pp. 21-29. doi:org/10.5539/esr.v9n2p21

Toteu, S.F., Penaye, J., and Djomani, Y.P., 2004, Geodynamic evolution of the Pan-African belt in central Africa with special reference to Cameroon. Canadian Journal of Earth Science, v. 41, pp. 73-85.

Toteu, S.F., Michard, A., Bertrand, J.M., and Rocci, G., 1987, U/Pb of Precambrian rocks from Northern Cameroon, orogenic evolution and chronology of the Pan-African Belt of Central Africa. Precambrian Research, v. 37, pp. 71-87.

Toteu, S.F., Van Schmus, W.R., Penaye, J., and Michard, A., 2001, New U$\mathrm{Pb}$ and $\mathrm{Sm}-\mathrm{Nd}$ data from north-central Cameroon and its bearing on pre-Pan African history of central Africa. Precambrian Research, v. 108, pp. 45-73.

Trail, D., Watson, E.B., and Tailby, N.D., 2011, Ce and Eu anomalies in zircon as proxies for the oxidation state of magmas. Geochimica et
Cosmochimica Acta, v. 97, pp. 70-87.

Van Schmus, W.R., Oliveira E.P., da Silva Filho, A.F., Toteu, S.F., Penaye, J., and Guimaraes, I.P., 2008, Proterozoic links between the Borborema Province, NE Brazil, and the Central African Fold Belt. Geological Society of London, Special Publications, v. 294, pp. 69-99.

Vishiti, A., Etame, J., and Suh, C.E., 2019, Features of gold-bearing quartz veins in an artisanal mining-dominated terrain, Batouri gold district, Eastern region of Cameroon. Episodes, v. 42, pp. 199-212.

Vishiti, A., Suh, C.E., Lehmann, B., Egbe, J.A., and Shemang, E.M., 2015, Gold grade variation and particle microchemistry in exploration pits of the Batouri gold district, SE Cameroon. Journal of African Earth Sciences, v. 111, pp. 1-13.

Wiedenbeck, M., Allé, P., Corfu, F., Griffin, W.L., Meier, M., Oberli, F., Von Quadt, A., Roddick, J.C., and Spiegel, W., 1995, Three natural zircon standards for $\mathrm{U}-\mathrm{Th}-\mathrm{Pb}$, Lu-Hf, trace element and REE analyses. Geostand Newsletter, v. 19, pp. 1-23.

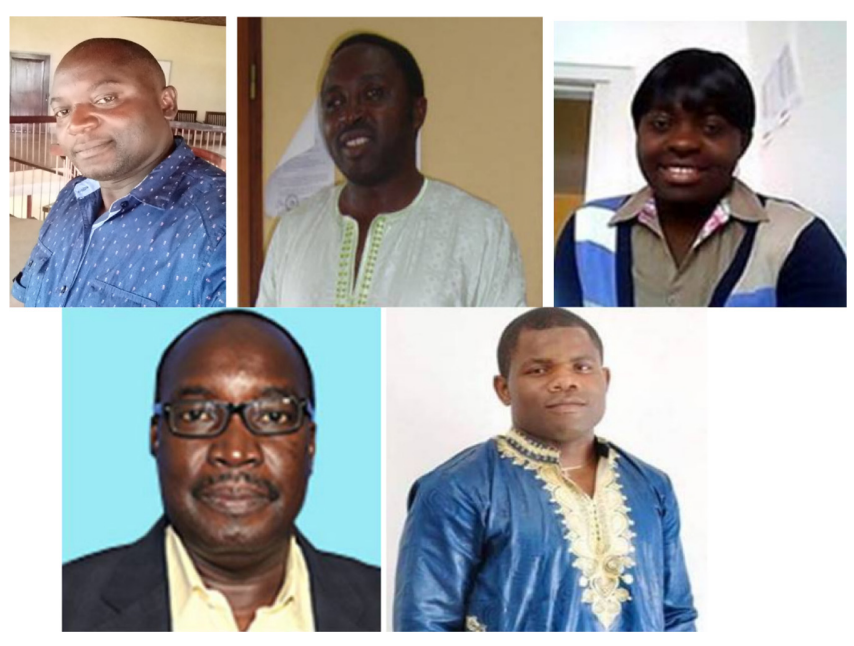

Top left to bottom right.

Enerst Tata (PhD) is Assistant Lecturer of Mining and Mineral Engineering at the University of Bamenda with keen interest in Mineral Deposit Evaluation and Ore Processing Engineering. His research is focused on gold and iron ore occurrence within the Precambrian mineral belt of Cameroon.

Cheo Emmanuel Suh is full Professor of Economic Geology and Microtectonics. He is Deputy Vice Chancellor at the University of Bamenda, and Fellow of the Alexander von Humboldt Foundation. He has developed various research projects in the area of Economic Geology with a focus on the Economic Geology of the Precambrian mineral belt of Cameroon.

Akumbom Vishiti (PhD) is an Economic Geologist at The University Institute of Technology (IUT), University of Douala. Her main research interests include ore processing and mining.

Elisha Mutum Shemang is full Professor of Geosciences and Dean of Postgraduate Studies at the Botswana International University of Science and Technology. His main research interest centres on geophysics and environmental geology/climate change.

Kevin Ijunghi Ateh holds a PhD from the University of Buea and he is an Assistant Lecturer of Mining and Mineral Engineering at the University of Bamenda with keen interest in gold ore deposits and mining. His main research is focussed on global gold and iron ore occurrence. 